\title{
Nutritional and Bread-Making Quality of Wheat as Influenced by Mineral Fertilization in a Compost-Amended Regosol soil
}

\author{
Mohammad Safar Noori", Hirofume Saneoka
}

Graduate School of Biosphere Science, Hiroshima University, Higashi-Hiroshima, 739-8528, Japan

\begin{abstract}
This experiment was conducted to assess the effect of different levels of nitrogen $(N)$, phosphorus $(P)$ and potassium $(K)$ fertilization on growth, grain yield, nutritional and bread-making quality of wheat in a compost-amended regosol soil. Wheat cultivar Minaminokaori was grown in containers containing a mixture of regosol and aerobic compost $(2: 1 \mathrm{v} / \mathrm{v})$. This study comprised a non-fertilized control $\left(F_{1}\right)$ and six levels of NPK fertilizers: $\mathrm{F}_{2}\left(80 \mathrm{~kg} \mathrm{~N}+40 \mathrm{~kg} \mathrm{P}_{2} \mathrm{O}_{5}+40 \mathrm{~kg} \mathrm{~K}_{2} \mathrm{O}\right.$ $\left.\mathrm{ha}^{-1}\right), \mathrm{F}_{3}\left(110 \mathrm{~kg} \mathrm{~N}+60 \mathrm{~kg} \mathrm{P}_{2} \mathrm{O}_{5}+55 \mathrm{~kg} \mathrm{~K} \mathrm{~K}_{2} \mathrm{Oha} \mathrm{h}^{-1}\right), \mathrm{F}_{4}$ $\left(140 \mathrm{~kg} \mathrm{~N}+80 \mathrm{~kg} \mathrm{P}_{2} \mathrm{O}_{5}+70 \mathrm{~kg} \mathrm{~K}_{2} \mathrm{O} \mathrm{ha}^{-1}\right), \mathrm{F}_{5}(170 \mathrm{~kg} \mathrm{~N}+$ $\left.100 \mathrm{~kg} \mathrm{P}_{2} \mathrm{O}_{5}+85 \mathrm{~kg} \mathrm{~K} \mathrm{O} \mathrm{ha}^{-1}\right), F_{6}(200 \mathrm{~kg} \mathrm{~N}+120 \mathrm{~kg}$ $\left.\mathrm{P}_{2} \mathrm{O}_{5}+100 \mathrm{~kg} \mathrm{~K}_{2} \mathrm{O} \mathrm{ha}^{-1}\right)$ and $\mathrm{F}_{7}\left(230 \mathrm{~kg} \mathrm{~N}+140 \mathrm{~kg} \mathrm{P}_{2} \mathrm{O}_{5}\right.$ $+115 \mathrm{~K}_{2} \mathrm{O} \mathrm{kg} \mathrm{ha} \mathrm{kg}^{-1}$ ). A significant improvement in agronomic performance, grain nutritional and breadmaking quality of wheat was observed with the $F_{6}$ treatment, it increased the grain yield (151.6\%), crude protein $(65.3 \%)$, water-soluble pentosan $(40.5 \%)$, and dry gluten (4-fold) compared to the control. The $F_{6}$ treatment also increased grain total $N, P, K, M g, C a, Z n$ and inorganic phosphorus contents by 65.2, 33.6, 8.9, 19.7, 165.9, 26.1 and $80.0 \%$, respectively, compared to control. However, it slightly increased grain phytate $P$ content. The results from this study suggest that agronomic performance, grain yield, nutritional and bread-making quality of wheat can be improved with an appropriate dose of NPK in a compost-amended regosol soil.
\end{abstract}

Keywords-Crude protein, Gluten, NPK, Pentosan, Phytate P, Wheat.

\section{INTRODUCTION}

Wheat is an important cereal crop in the world and is primarily grown for its grain, which is consumed as human food. It contributes about $20 \%$ of the total dietary calories and proteins worldwide (Shiferaw et al., 2013), and has gotten more attention for food security especially with fast growing populations in developing countries. Enhancing crop productivity and achieving food security is possible through a wise fertilizer application, particularly in regosol soil which is deficient in nutrient. NPK fertilization in balanced share at proper time has a great impact on wheat growth and yield (Malghani et al., 2010).

$\mathrm{N}$ is a key component of proteins, nucleic acids, enzymes, coenzymes, and chlorophyll and therefore contributes to the biochemical processes of the plant (Benin et al., 2012). $\mathrm{N}$ fertilization during anthesis has a positive effect on synthesis of high grain protein content than earlier application (Wuest and Cassman, 1992). An adequate level of $\mathrm{N}$ fertilization increases the number of fertile tillers (Wilhelm, 1998), number of spikes, number of grains per spike, and grains yield (Al-Abdulsalam, 1997). Application of $\mathrm{P}$ enhances seed maturity and development (Ziadi et al., 2008), and adequate supply of $\mathrm{P}$ can increase grain yield of wheat by $20 \%$ (Ascher et al., 1994). More than $70 \%$ of grain total $\mathrm{P}$ is stored as phytic acid in seeds (Rosa, 1999). K plays a significant role in plant biochemical functions such as activation of various enzymes, synthesis of protein and carbohydrates, enhancement of fat content, improving drought tolerance, and resistance to frost and lodging (Marschner, 1995). An optimum rate of $\mathrm{K}$ fertilization increases number of productive tillers, number of grain per spike, 1000 grain weight, grain yield, and protein content of wheat (Alam et al., 2009).

Phytic acid (phytate) is the main phosphorus storage form in most cereals, legumes and nuts (Lopez et al., 2002). It is considered as an anti-nutritional factor that complex with proteins and chelates with some nutritionally important micronutrients ( $\mathrm{Fe}, \mathrm{Zn}, \mathrm{Mg}$, and $\mathrm{Ca}$ ) and resulting in a significant decrease in the bioavailability of these nutrients (Raboy, 2001). Pentosans are the major non-starch polysaccharides and is divided into water-soluble pentosan and water unextractable solids. Water-soluble pentosan has a positive effect on dough rheological characteristics and macaroni production processing (Menger, 1976). Pentosan added to the dough increased dough development time, water-binding capacity and viscosity of dough (Jelaca and Hlynka, 1971).

Determination of grain nutrients, pentosan, gluten and phytate $\mathrm{P}$ content of wheat under different soil fertility is important as they influence nutritional quality and bread- 
making characteristics of flour. Therefore, the present experiment was conducted to study the effects of different levels of NPK on yield, grain minerals, crude protein, pentosan, gluten and phytate $\mathrm{P}$ content of wheat in a compost-amended regosol soil.

\section{MATERIALS AND METHODS}

The experiment was conducted in a greenhouse of the Faculty of Applied Biological Sciences, Hiroshima University. Conditions in the greenhouse were $65 \%$ humidity, $20-25{ }^{\circ} \mathrm{C}$ day $/ 15-18{ }^{\circ} \mathrm{C}$ night temperatures, and natural sunlight. Containers $(1.5 \mathrm{~m}$ length, $30 \mathrm{~cm}$ width, and $18 \mathrm{~cm}$ in depth) were used, and filled with a mixture of regosol and aerobic compost (2:1). Chemical analysis of this mixture showed that it contained; $0.2 \%$ total N, 6.8 $\mathrm{mg} \mathrm{kg}^{-1}$ available $\mathrm{P}$ and $79.6 \mathrm{mg} \mathrm{kg}^{-1}$ available K. Soil $\mathrm{pH}$ $\left(\mathrm{H}_{2} \mathrm{O}\right)$ was adjusted to 6.5 by adding 1 ton $\mathrm{ha}^{-1}$ of dolomitic calcium magnesium carbonate. This investigation comprised a control $\left(\mathrm{F}_{1}\right.$, non-fertilized) and six levels of NPK fertilizers: $\mathrm{F}_{2}\left(80 \mathrm{~kg} \mathrm{~N}+40 \mathrm{~kg} \mathrm{P}_{2} \mathrm{O}_{5}+40\right.$ $\left.\mathrm{kg} \mathrm{K}_{2} \mathrm{O} \mathrm{ha}^{-1}\right), \mathrm{F}_{3}\left(110 \mathrm{~kg} \mathrm{~N}+60 \mathrm{~kg} \mathrm{P}_{2} \mathrm{O}_{5}+55 \mathrm{~kg} \mathrm{~K}_{2} \mathrm{O}\right.$ ha $\left.{ }^{1}\right), \mathrm{F}_{4}\left(140 \mathrm{~kg} \mathrm{~N}+80 \mathrm{~kg} \mathrm{P}_{2} \mathrm{O}_{5}+70 \mathrm{~kg} \mathrm{~K}_{2} \mathrm{O} \mathrm{ha}^{-1}\right), \mathrm{F}_{5}(170$ $\left.\mathrm{kg} \mathrm{N}+100 \mathrm{~kg} \mathrm{P}_{2} \mathrm{O}_{5}+85 \mathrm{~kg} \mathrm{~K}_{2} \mathrm{O} \mathrm{ha}^{-1}\right), \mathrm{F}_{6}(200 \mathrm{~kg} \mathrm{~N}+120$ $\left.\mathrm{kg} \mathrm{P}_{2} \mathrm{O}_{5}+100 \mathrm{~kg} \mathrm{~K}_{2} \mathrm{O} \mathrm{ha}^{-1}\right)$ and $\mathrm{T}_{7}(230 \mathrm{~kg} \mathrm{~N}+140 \mathrm{~kg}$ $\left.\mathrm{P}_{2} \mathrm{O}_{5}+115 \mathrm{~K}_{2} \mathrm{O} \mathrm{kg} \mathrm{ha}{ }^{-1}\right)$. The source of NPK was urea, single super phosphate, and potassium sulfate, respectively. All $\mathrm{P}, \mathrm{K}$ and half dose of $\mathrm{N}$ were applied before sowing, and the remaining $\mathrm{N}$ was applied in two equal splits at tillering and anthesis stages. Minaminokaori, a commonly grown wheat cultivar in Japan was sown in the third week of November, then, tenday-old seedlings were transplanted into the containers with $10 \mathrm{~cm}$ distance, following a randomized complete block design with 4 replicates. During the experiment all agronomic management practices were performed uniformly as required.

\subsection{Growth, Yield, and Yield component:}

Twenty plants (5 from each replicates) were randomly taken and the following yield components were evaluated: Number of tillers per plant was obtained by counting all tillers produced in each plant before harvest. Number of spikes were counted in each plant by the time of harvest. Number of grains per spike was obtained by counting grains in 10 spikes which were randomly collected from each treatment. To measure 1000 grain weight, 500 grains were counted and weighted with a prescribed accuracy, and then the value was multiplied by 2 . To measure grain yield, mature spikes were collected, oven dried at $80^{\circ} \mathrm{C}$ for 48 hours, threshed, and the grain yield was recorded and expressed in kg per hectare. Crop growth rate (CGR) was calculated as plant's dry weight increase per unit of time (Nogueira et al., 1994).

$$
\mathrm{CGR}=\left(\mathrm{W}_{2}-\mathrm{W}_{1}\right) /\left(\mathrm{T}_{2}-\mathrm{T}_{1}\right)
$$

Where: $\mathrm{W}_{1}$ and $\mathrm{W}_{2}=$ total dry weight of plant at first and second sampling; $\mathrm{T}_{1}$ and $\mathrm{T}_{2}=$ time of first and second sampling.

\subsection{Grain mineral content}

Samples of mature seeds were ground finely with a vibrating sample mill (TI-100, Heiko, Japan) and grain minerals contents were measured. The grain powdered samples were digested by sulfuric acid and heating, then they were diluted with distilled water, and $\mathrm{K}$ content was measured using flame photometer (ANA 135, Tokyo Photoelectric, Tokyo, Japan). Total $\mathrm{P}$ was determined in the same digested samples by UV-Spectrophotometer (U3310, Hitachi Co. Ltd. Tokyo, Japan), following the molybdenum reaction solution method suggested by Chen et al. (1956). Grain $\mathrm{Ca}, \mathrm{Mg}$ and $\mathrm{Zn}$ concentration were measured by an atomic absorption flame emission spectrophotometer (AA-6200, Shimadzu, Japan). Total N was measured using the Kjeldahl method after digestion with concentrated $\mathrm{H}_{2} \mathrm{SO}_{4}$ and $\mathrm{H}_{2} \mathrm{O}_{2}(10: 5$, v/v). Grain inorganic Phosphorus $(\mathrm{Pi})$ was extracted in trichloroacetic acid $(12.5 \%)+\mathrm{MgCl}_{2}(2 \mathrm{mmol} / \mathrm{l})$ while stirring overnight, and $\mathrm{Pi}$ was measured colorimetrically, using a spectrophotometer following the molybdenum reaction regent method (Raboy and Dickinson, 1984).

\subsection{Determination of grain starch and crude protein}

To measure grain starch content, ethanol $(80 \%)$ was added to the powdered samples to remove sugars and then starch was extracted with perchloric acid. Anthrone reagent was added to the test tubes containing extracted samples and then heated in a boiling water bath for 7.5 minutes. The absorbance of the extract was measured at $630 \mathrm{~nm}$ (Nag, 2016). To determine grain crude protein, the observed total $\mathrm{N}$ content from the Kjeldahl method was multiplied by 5.47 (Fujihara et al., 2008).

\subsection{Determination of total pentosan and water-soluble pentosan}

Total pentosan was measured using the orcinolhydrochloric acid method, where finely ground samples were hydrolyzed with $2 \mathrm{~N}$ hydrochloric acid in a boiling water bath for 2.5 hours, and then centrifuged. A specific quantity of supernatants was transferred to the new test tubes and reaction regents $\left(\mathrm{FeCl}_{3}\right.$ and orcinol) were added and vortexed. The tubes were heated in boiling water for 30 minutes, cooled, and the absorbance was measured using a spectrophotometer. Grain water-soluble pentosan was extracted by hydrolyzing powdered samples in distilled water with shaking for 2 hours at $30^{\circ} \mathrm{C}$. Then, 4 $\mathrm{N}$ hydrochloric acid was added to the aliquots of the supernatant and placed in boiling water for 2 hours, and allowed to cool, and grain water-soluble pentosan content was measured by a spectrophotometer, using $\mathrm{FeCl}_{3}$-orcinol reagents (Hashimoto et al., 1986).

2.5 Determination of gluten and phytate $P$ content 
Gluten content was measured according to (AACC) international approved method by hand washing with 30 minutes resting time, and the result was expressed as dry gluten percentage. Grain phytate $\mathrm{P}$ was measured according to the method suggested by Raboy and Dickinson (1984), where aliquots of flour were extracted in extraction media $\left(0.2 \mathrm{M} \mathrm{HCl}: 10 \% \mathrm{Na}_{2} \mathrm{SO}_{4}\right)$ overnight at $4{ }^{\circ} \mathrm{C}$ with shaking. Extracts were centrifuged and phytate was obtained as a ferric precipitate and assayed for $\mathrm{P}$ colorimetrically using ammonium molybdate reaction reagent.

\subsection{Statistical analysis}

All the collected data were subjected to analysis of variance using SPSS statistics package, Student Version 19 , and means $(n=4)$ were separated using the Duncan Multiple Range Test at $\mathrm{p}=0.05$.

\section{RESULT AND DISCUSSION}

\subsection{Agronomic performance and yield}

Crop growth rate (CGR) was significantly affected by different levels of NPK fertilization (Figure 1). There was a linear increase in CGR with an increase in NPK levels but further increase in NPK $\left(\mathrm{F}_{7}\right)$ did not enhance CGR significantly compared to $\mathrm{F}_{5}$. This result is in agreement with Laghari et al. (2010) and Asghar et al. (2010) who found that further increase in NPK levels had a nonsignificant response. The result of this study indicated that NPK fertilization significantly increased the number of tillers per plant. The highest number of tillers was observed in plants where a high $\operatorname{NPK}\left(\mathrm{F}_{7}\right)$ was applied (Table 1). There was a progressive increase in the number of tillers with increased levels of NPK. Similar findings were reported by Kausar et al. (1993) and Niamatullah et al. (2011) indicating that high level of NPK significantly increased the number of tillers in wheat. The mean number of spike per plant was ranged from 5.5 to 13.35 . NPK fertilization enhanced the number of spike per plant and the highest number of spike per plant was observed with $\mathrm{F}_{6}$ treatment (Table 1). The high rate of NPK $\left(\mathrm{F}_{7}\right)$ did not increase the number of spikes per plant because of prolonged vegetative growth which resulted in the production of more number of infertile tillers. These findings are in agreement with Hussain et al. (2002) who reported a decrease in the number of fertile tillers due to the application of a high rate of NPK. Similarly, Ali and Yasin (1991) found that high dose of $N$ and $P$ reduced the number of the spike in wheat. The maximum number of grains per spike was obtained with $\mathrm{F}_{7}$ treatment. However, the number of grains produced by $\mathrm{F}_{6}, \mathrm{~F}_{5}, \mathrm{~F}_{4}$, and $\mathrm{F}_{3}$ treatments were statistically similar (Table 1). The reason for high number of grains per spike in $\mathrm{F}_{7}$ might be due to higher rate of $\mathrm{N}$ and $\mathrm{P}$ which enhanced seed set in the spike (Hussain et al., 2002; Alam, et al., 2007; Malghani et al., 2010). The 1000 grain weight as an important yield contributing parameter was higher in plants which were supplied with a high rate of NPK. $F_{7}$ and $F_{6}$ treatments recorded the higher value for 1000 grain weight compared to control (Table 1). The moderate fertilizer levels $\left(\mathrm{F}_{5}, \mathrm{~F}_{4}\right.$, $\mathrm{F}_{3}$, and $\mathrm{F}_{2}$ ) produced statistically similar 1000 grain weight. Significant effects of NPK fertilization on 1000 grain weight of cereals were also reported by Maqsood et al. (2001) and Asghar et al. (2010).

Grain yield was significantly affected by different levels of NPK fertilization. Application of $F_{6}$ and $F_{7}$ resulted in increased number of fertile tillers, number of grains per spike and maximum 1000 grain weight which eventually contributed to the production of a higher grain yield. F6 treatment resulted in $151.64 \%$ increase in grain yield over control. There was a slight decrease in grain yield of plants with $\mathrm{F}_{7}$ treatment, compared to $\mathrm{F}_{6}$ that might be due to the $\mathrm{N}$ interaction with P and K (MacLeod, 1969). Niamatullah et al. (2011), Khursheed and Mahammad (2015), and Abdul-Aziz et al. (2016) also concluded that grain yield of wheat and cereal crops can be increased with application of $\mathrm{N}, \mathrm{P}$, and $\mathrm{K}$ fertilizers.

\subsection{Grain mineral content}

Grain minerals contents were significantly influenced by NPK fertilization. Plants with $\mathrm{F}_{6}$ treatment recorded higher grain total $\mathrm{N}, \mathrm{P}, \mathrm{K}, \mathrm{Pi}, \mathrm{Mg}$, and $\mathrm{Zn}$ content. It was observed that further increase in NPK dose $\left(\mathrm{F}_{7}\right)$ only increased $\mathrm{Ca}$ content but the contents of N, P, K, Pi and $\mathrm{Zn}$ were slightly reduced in $F_{7}$ treated plants (Table 2). Gain $\mathrm{Zn}$ content was enhanced with application of high and moderate levels of NPK fertilization. In general, $F_{6}$ treatment increased grain total $\mathrm{N}, \mathrm{P}, \mathrm{K}, \mathrm{Mg} \mathrm{Ca}, \mathrm{Zn}$ and $\mathrm{Pi}$ contents by $65.2,33.6,8.9,19.7,165.9,26.13$ and $80 \%$, respectively, compared to control. Laghari et al. (2010) also found that NPK fertilization increased mineral uptake particularly, N, K and P in wheat. Application of high $\mathrm{N}$ fertilizer enhanced $\mathrm{K}$ accumulation in wheat grains (Sheoran et al., 2015). Saha et al. (2014) found that application of $\mathrm{P}$ fertilizer enhanced $\mathrm{P}$ content in wheat grains. While, application of very high dose of $\mathrm{N}$ did not enhance grain total $\mathrm{P}$ content of wheat (Akhtar et al. (2011). In this study the decrease in grain mineral content with $\mathrm{F}_{7}$ treatment might be due to prolonged vegetative growth and excessive biomass production that reduced grain mineral content in wheat grains. 
Table 1. Effect of NPK fertilization on number of tillers plant-1, number of spikes plant-1, number of grains spike-1, 1000 grain weight, and grain yield of wheat. The same letter indicates no significant difference $(p \leq 0.05)$.

\begin{tabular}{|c|c|c|c|c|c|}
\hline $\begin{array}{l}\text { NPK } \\
\text { levels }\end{array}$ & $\begin{array}{l}\text { Number } \\
\text { of tillers }\end{array}$ & $\begin{array}{l}\text { Number } \\
\text { of spikes }\end{array}$ & $\begin{array}{l}\text { Number } \\
\text { of grains }\end{array}$ & 1000 grain & Grain yield \\
\hline & $\left(\right.$ plant $\left.^{-1}\right)$ & $\left(\right.$ plant $\left.^{-1}\right)$ & $\left(\right.$ spike $\left.^{-1}\right)$ & (g) & $\left(\right.$ ton $\left.\mathrm{ha}^{-1}\right)$ \\
\hline$F_{1}$ & $5.55^{\mathrm{e}}$ & $5.45^{\mathrm{d}}$ & $36.85^{\mathrm{b}}$ & $42.03^{c}$ & $2.77^{\mathrm{c}}$ \\
\hline$F_{2}$ & $13.96^{\mathrm{d}}$ & $9.60^{\mathrm{c}}$ & $37.15^{\mathrm{b}}$ & $45.82^{\mathrm{ab}}$ & $4.52^{\mathrm{bc}}$ \\
\hline$F_{3}$ & $14.10^{\mathrm{d}}$ & $9.67^{\mathrm{c}}$ & $39.30^{\mathrm{ab}}$ & $46.29^{\mathrm{ab}}$ & $5.03^{\mathrm{b}}$ \\
\hline$F_{4}$ & $18.30^{c}$ & $10.80^{\mathrm{bc}}$ & $40.35^{\mathrm{ab}}$ & $46.33^{\mathrm{ab}}$ & $5.22^{\mathrm{b}}$ \\
\hline$F_{5}$ & $19.40^{\mathrm{bc}}$ & $11.30^{\mathrm{bc}}$ & $40.41^{\mathrm{ab}}$ & $46.91^{\mathrm{ab}}$ & $5.53^{\mathrm{b}}$ \\
\hline$F_{6}$ & $21.30^{\mathrm{ab}}$ & $13.35^{\mathrm{a}}$ & $41.00^{\mathrm{ab}}$ & $47.57^{\mathrm{a}}$ & $6.97^{\mathrm{a}}$ \\
\hline $\mathbf{F}_{7}$ & $23.40^{\mathrm{a}}$ & $12.20^{\mathrm{ab}}$ & $43.10^{\mathrm{a}}$ & $47.90^{\mathrm{a}}$ & $6.9^{\mathrm{a}}$ \\
\hline
\end{tabular}

Table 2. Effect of NPK fertilization on grain mineral content in wheat grain. The same letter indicates no significant difference $(p \leq 0.05)$.

\begin{tabular}{|l|l|l|l|l|l|l|l|}
\hline NPK levels & $\mathrm{N}$ & $\mathrm{P}$ & $\mathrm{K}$ & $\mathrm{Pi}$ & $\mathrm{Mg}$ & $\mathrm{Ca}$ & $\mathrm{Zn}$ \\
\hline & $\left(\mathrm{mg} \mathrm{g}^{-1}\right)$ & $\left(\mathrm{mg} \mathrm{g}^{-1}\right)$ & $\left(\mathrm{mg} \mathrm{g}^{-1}\right)$ & $\left(\mathrm{mg} \mathrm{g}^{-1}\right)$ & $\left(\mathrm{mg} \mathrm{g}^{-1}\right)$ & $\left(\mu \mathrm{g} \mathrm{g}^{-1}\right)$ & $\left(\mu \mathrm{g} \mathrm{g}^{-1}\right)$ \\
\hline $\mathbf{F}_{1}$ & $16.01^{\mathrm{d}}$ & $3.42^{\mathrm{c}}$ & $4.72^{\mathrm{b}}$ & $0.247^{\mathrm{c}}$ & $1.32^{\mathrm{e}}$ & $71.04^{\mathrm{c}}$ & $74.66^{\mathrm{b}}$ \\
\hline $\mathbf{F}_{2}$ & $18.07^{\mathrm{cd}}$ & $4.01^{\mathrm{b}}$ & $4.68^{\mathrm{ab}}$ & $0.349^{\mathrm{b}}$ & $1.35^{\mathrm{de}}$ & $74.61^{\mathrm{c}}$ & $81.47^{\mathrm{ab}}$ \\
\hline $\mathbf{F}_{3}$ & $21.10^{\mathrm{bc}}$ & $4.11^{\mathrm{b}}$ & $4.89^{\mathrm{ab}}$ & $0.369^{\mathrm{b}}$ & $1.43^{\mathrm{cd}}$ & $107.89^{\mathrm{bc}}$ & $87.97^{\mathrm{a}}$ \\
\hline $\mathbf{F}_{4}$ & $21.40^{\mathrm{bc}}$ & $4.25^{\mathrm{ab}}$ & $4.92^{\mathrm{ab}}$ & $0.383^{\mathrm{ab}}$ & $1.48^{\mathrm{bc}}$ & $147.98^{\mathrm{ab}}$ & $88.87^{\mathrm{a}}$ \\
\hline $\mathbf{F}_{\mathbf{5}}$ & $22.93^{\mathrm{ab}}$ & $4.31^{\mathrm{ab}}$ & $4.98^{\mathrm{ab}}$ & $0.396^{\mathrm{ab}}$ & $1.52^{\mathrm{abc}}$ & $150.43^{\mathrm{ab}}$ & $90.99^{\mathrm{a}}$ \\
\hline $\mathbf{F}_{\mathbf{6}}$ & $26.45^{\mathrm{a}}$ & $4.57^{\mathrm{a}}$ & $5.14 \mathrm{a}$ & $0.445^{\mathrm{a}}$ & $1.58^{\mathrm{a}}$ & $188.95^{\mathrm{a}}$ & $94.17^{\mathrm{a}}$ \\
\hline $\mathbf{F}_{7}$ & $24.95^{\mathrm{ab}}$ & $4.35^{\mathrm{ab}}$ & $5.00^{\mathrm{ab}}$ & $0.407^{\mathrm{ab}}$ & $1.54^{\mathrm{ab}}$ & $197.14^{\mathrm{a}}$ & $92.29^{\mathrm{a}}$ \\
\hline
\end{tabular}

\subsection{Grain starch and crud protein content}

Analysis of data showed that NPK fertilization did not affect grain starch content significantly. Control $\left(\mathrm{F}_{1}\right)$ recorded a higher value for grain starch, while with increase in NPK level grain starch content was slightly decreased. Kindred et al. (2008) observed that application of $\mathrm{N}$ fertilizer decreased the starch content of wheat grain. There is a negative relationship between crude protein and starch as the grain yield and crude protein increases with higher rate of fertilizers, the starch content decreases (Hlisnikovsky and Kunzova, 2014). A decrease in grain starch content due to fertilizer application was also reported by Crista et al. (2012) indicating that starch content was higher in plants with no fertilizer application. The highest grain crude protein $(\%)$ was observed with $\mathrm{F}_{6}$ treated plants followed by $\mathrm{F}_{7}$ and $\mathrm{F}_{5}$.

However, the lowest crude protein was recorded in $F_{1}$ where no fertilizer was applied. There was a linear increase in crude protein with increase in NPK level up to $F_{6}$, but further increase in NPK rate $\left(F_{7}\right)$ slightly reduced crude protein content of wheat grain (Table 3). $F_{6}$ treatment increased grain crude protein by $65.3 \%$ compared to control. Application of excessive NPK fertilizers reduced grain crude protein content. This result agrees with Sameen et al. (2002) who found a reduction in crude protein content of wheat cultivar V-94091 and Vwww.ijeab.com
94105 due to the highest rate of NPK fertilizers. Similarly, Crista et al. (2012) found that NPK fertilization enhanced the synthesis of the raw protein in wheat. $\mathrm{N}$ fertilizer plays a significant role in total $\mathrm{N}$ and crude protein accumulation in wheat grains, while application of high dose of $\mathrm{N}$ beyond the optimum level may have a negative effect on grain crude protein (Abedi et al., 2011).

\subsection{Grain total and water-soluble pentosan content}

Grain total pentosan content was decreased with increase in NPK level the highest value of total pentosan recorded with $F_{1}$ treatment where no fertilizer was applied. Plants supplied with different levels of NPK fertilizers, recorded statistically similar total pentosan content. The effect of NPK fertilization on the grain total pentosan and watersoluble pentosan contents of wheat has not been reported sufficiently by earlier researchers. The major proportion of total pentosan is water-unextractable pentosan which forms physical barriers for the gluten network during dough development. Unlike to total pentosan, grain watersoluble pentosan content was enhanced with application of NPK, and $\mathrm{F}_{6}$ treatment recorded the highest value of grain water-soluble pentosan content. The $\mathrm{F}_{6}$ treatment increased grain water-soluble pentosan content by $40.5 \%$ compared to control. Water-soluble pentosan plays a key role in bread-making quality of dough. It increases the viscosity

Page | 3188 
and the stability of dough foam structure, which helps in a bigger loaf volume and a finer homogeneous bread crumb (Courtin and Delcour, 2002).

\subsection{Grain dry gluten content}

Gluten is responsible for the unique elasticity and stickiness of wheat dough, the properties that make it so useful in bread-making. In this study, grain dry gluten content was increased with increase in NPK level, and among the various levels of NPK $\mathrm{F}_{6}$ and $\mathrm{F}_{7}$ treatments recorded a higher dry gluten content. The $\mathrm{F}_{6}$ treatment increased grain dry gluten by 4-fold compared to control. A slight decrease was observed with application of the highest NPK level $\left(\mathrm{F}_{7}\right)$ that might be because of decrease in protein content due to excess NPK application, as explained earlier in case of crude protein content. Mineral fertilization increased the gluten content of wheat compared to a control, but various levels of $\mathrm{P}$ and $\mathrm{K}$ did not affect grain gluten significantly (Gaj et al., 2013).

\subsection{Grain phytate $P$ content}

Analysis of variance showed that $F_{6}$ and $F_{7}$ treatments recorded a higher grain phytate $\mathrm{P}$ content compared to $\mathrm{F}_{1}$ (Table 3). Phytate is the major storage form of phosphorous in cereals, therefore the content of phytate $\mathrm{P}$ mostly depends on total grain P. Phytate P can contribute to the nutritional deficiencies when seeds are used as food
(Rosa 1999; Raboy 2001). It binds with proteins and important minerals such as $\mathrm{Fe}, \mathrm{Ca}$ and $\mathrm{Zn}$, and reduces their availability (Raboy, 2001). There was no sufficient review on the effect of NPK fertilization on phytate $P$ content of wheat grain. The increase in grain phytate $\mathrm{P}$ content with a higher dose of NPK fertilization might be associated with grain total $\mathrm{P}$ content which is enhanced by a higher rate of $\mathrm{P}$ fertilizer.

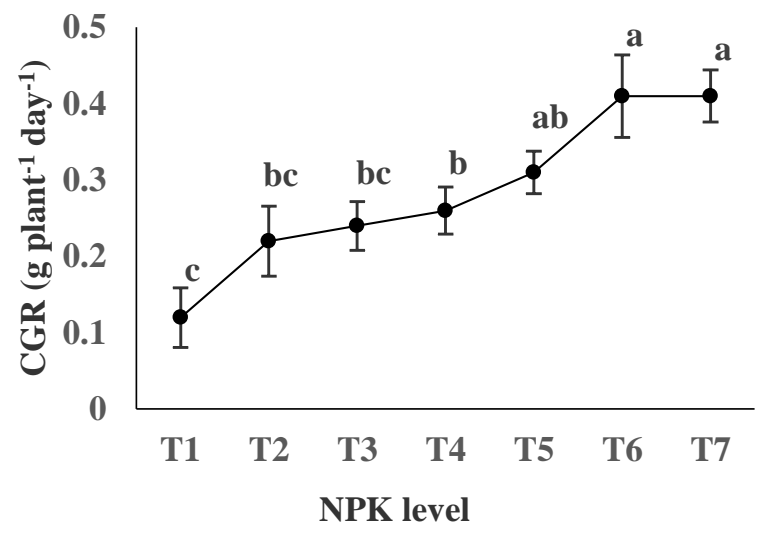

Fig. 1: Effect of NPK fertilization on crop growth rate (CGR). The same letter indicates no significant difference ( $p \leq 0.05)$.

Table 3. Effect of NPK fertilization on grain starch, crude protein, total pentosan, water-soluble pentosan and phytate $P$ content of wheat. The same letter indicates no significant difference $(p \leq 0.05)$.

\begin{tabular}{|l|l|l|l|l|l|l|}
\hline Treatment & Starch & Crude protein & $\begin{array}{l}\text { Total } \\
\text { pentosan }\end{array}$ & $\begin{array}{l}\text { Water-soluble } \\
\text { pentosan }\end{array}$ & Dry gluten & Phytate P \\
\hline & $(\%)$ & $(\%)$ & $\left(\mathrm{mg} \mathrm{g}^{-1}\right)$ & $\left(\mathrm{mg} \mathrm{g}^{-1}\right)$ & $(\%)$ & $\left(\mathrm{mg} \mathrm{g}^{-1}\right)$ \\
\hline $\mathbf{F}_{1}$ & $65.08^{\mathrm{a}}$ & $8.87^{\mathrm{d}}$ & $8.58^{\mathrm{a}}$ & $1.11^{\mathrm{b}}$ & $3.7^{\mathrm{c}}$ & $3.14^{\mathrm{c}}$ \\
\hline $\mathbf{F}_{2}$ & $64.23^{\mathrm{a}}$ & $10.00^{\mathrm{cd}}$ & $7.78^{\mathrm{ab}}$ & $1.23^{\mathrm{b}}$ & $6.7^{\mathrm{bc}}$ & $3.26^{\mathrm{bc}}$ \\
\hline $\mathbf{T}_{3}$ & $62.98^{\mathrm{a}}$ & $11.69^{\mathrm{bc}}$ & $7.75^{\mathrm{ab}}$ & $1.34^{\mathrm{ab}}$ & $8.5^{\mathrm{b}}$ & $3.52^{\mathrm{b}}$ \\
\hline $\mathbf{F}_{4}$ & $62.93^{\mathrm{a}}$ & $11.85^{\mathrm{bc}}$ & $7.00^{\mathrm{b}}$ & $1.41^{\mathrm{ab}}$ & $12.3^{\mathrm{b}}$ & $3.64^{\mathrm{ab}}$ \\
\hline $\mathbf{F}_{\mathbf{5}}$ & $63.00^{\mathrm{a}}$ & $12.72^{\mathrm{ab}}$ & $6.94^{\mathrm{b}}$ & $1.49^{\mathrm{a}}$ & $16.5^{\mathrm{ab}}$ & $3.75^{\mathrm{ab}}$ \\
\hline $\mathbf{T}_{\mathbf{6}}$ & $63.02^{\mathrm{a}}$ & $14.66^{\mathrm{a}}$ & $7.24^{\mathrm{b}}$ & $1.56^{\mathrm{a}}$ & $18.9^{\mathrm{a}}$ & $3.86^{\mathrm{a}}$ \\
\hline $\mathbf{F}_{7}$ & $63.00^{\mathrm{a}}$ & $13.82^{\mathrm{ab}}$ & $6.93^{\mathrm{b}}$ & $1.51^{\mathrm{a}}$ & $18.7^{\mathrm{a}}$ & $3.82^{\mathrm{a}}$ \\
\hline
\end{tabular}

\section{CONCLUSION}

The present results showed that different levels of NPK fertilization significantly influenced growth, yield, and grain nutritional and bread-making quality of wheat in a compost-amended regosol soil. $\mathrm{F}_{6}$ treatment resulted in the production of higher grain yield, increased grain minerals contents, crude protein, water-soluble pentosan, and dry gluten content. $\mathrm{F}_{6}$ treatment reduced the total pentosan, but did not significantly affect the level of grain starch content. By increasing the rate of NPK fertilization beyond $F_{6}$ treatment, only vegetative growth was enhanced. Therefore, $\mathrm{F}_{6}$ treatment might have been an appropriate and economical rate of NPK to obtain maximum grain yield and improve grain nutritional and bread-making quality of wheat cultivar Minaminokaori in a compostamended regosol soil.

\section{REFERENCES}

[1] Abdel-Aziz, Heba M. M.; Hasaneen, Mohammed N. A.; Omer, Aya M. (2016). Nano chitosan-NPK fertilizer enhances the growth and productivity of wheat plants grown in sandy soil. Span. J. Agric. Res., doi:http://dx.doi.org/10.5424/sjar/2016141$\underline{8205}$.

[2] Abedi, T., A. Alemzadeh, Kazemeini S. A. (2011). Wheat yield and grain protein response to Nitrogen amount and timing. Aust. J. Crop Sci., 5: 330-336. 
[3] Akhtar, M., A. Naeem, J. Akhter, S. A. Bokhari, Ishaque W. (2011). Improvement in nutrient uptake and yield of wheat by combined use of urea and compost. Soil Environ, 30: 45-49.

[4] Al-Abdul Salam, M. A. (1997). Influence of nitrogen fertilization rates and residual effect of organic manure rates on the growth and yield of wheat. Arab Gulf J. Sci. Res., 15: 647-60.

[5] Alam, M. R., M. Akkas Ali, M.S.H. Molla, M. A. Momin, Mannan M. A. (2009). Evaluation of different levels of $\mathrm{K}$ on yield and protein content of wheat in the high Ganges river floodplain soil. Bangladesh J. Agril. Res. 34: 97-104.

[6] Alam, M. Z., S. A. Haider, Paul N. K. (2007). Yield and yield components of Barley (Hordium vulgare L.) cultivars in relation to $\mathrm{N}$ fertilizer. J. Applied Sci. Res., 3: 1022-1026.

[7] Alam, S. M., Azam S., Ali S., Iqbal M., (2003). Wheat yield and P fertilizer efficiency as influenced by rate and integrated use of chemical and organic fertilizers. Pak. J. Soil Sci., 22: 72-76.

[8] Ali, R. and Yasin M. (1991). Response of wheat to $\mathrm{N}$ and phosphorus fertilization. Pakistan J. Agri. Res., 12: 130-3.

[9] Ascher, J.S., R.D. Graham, D.E. Elliott, J.M. Scott, Jessop R. S. (1994). Agronomic value of seed with high nutrient content. In D.A Saunders and G.P. Hettel, eds. Wheat in heat-stressed environments: irrigated, dry area and rice-wheat farming systems. CIMMYT, Mexico.

[10] Asghar, A. A. Ali, W. H. Syed, M. Asif, T. Khaliq, Abid A. (2010). Growth and yield of maize (Zea mays L.) cultivars affected by NPK application in different proportion. Pak. J. Sci., 62: 211-216.

[11] Benin, G., Elesandro Bornhofen, Eduardo Beche, Eduardo Stefani Pagliosa, Cristiano Lemes da Silva, Pinnow C. (2102). Agronomic performance of wheat cultivars in response to nitrogen fertilization levels. Acta. Sci., Agron., 34: 275-283.

[12] Chen, P.S., T.Y. Toribara, Warner H. (1956). Microdetermination of phosphorus. Anal Chem., 28: 1756-1756.

[13] Courtin, C. M., Delcour, J. A. (2002) Arabinoxylans and endoxylanases in wheat flour bread-making. $J$. Cereal Sci., 35: 225-243.

[14] Crista, F., Isidora Radulovi, Florin Sala, Laura Crista, Berbecea A. (2012). Influence of NPK fertilizer upon winter wheat grain quality. Res. J. Agric. Sci., 44: 30-35.

[15] Fujihara, S., H. Sasaki, Aoyagi Y., Sugahara T. (2008). Nitrogen-to-protein conversion factors for some cereal products in Japan. J Food Sci., 73: 204209.
[16] Garg, B. K., Burman U., Kathju S. (2004). The influence of phosphorus nutrition on the physiological response of mothbean genotypes to drought. J. Plant Nutr. Soil Sci., 167: 503-508.

[17] Hashimoto, S., Shogren M. D., Pomeranz Y. (1986). Cereal pentosans: Their estimation and significance. I. Pentosans in wheat and milled wheat products. Cereal chem., 64: 30-34.

[18] Hlisnikovsky, L., Kunzova E. (2014). Effect of mineral and organic fertilizers on yield and technological parameters of winter wheat (Triticum aestivum L.) on Illimerized Luvisol. Polish J. Agron., 17: 18-24

[19] Hussain, M. I., Shamshad H. Shah, Sajad Hussain, Iqbal K. (2002). Growth, Yield and Quality Response of Three Wheat (Triticum aestivum L.) Varieties to Different Levels of N, P and K. Int. J. Agri. Biol., 4: 361-364.

[20] Jelaca, S. L. and Hlynka I. (1971). Water-binding capacity of wheat flour crude pentosans and their relation to mixing characteristics of dough. Cereal Chem., 48: 211-222.

[21] Kausar, K., Muhammad Akbar, E. Rashad, Abid Nisar A. (1994). Physiological response of nitrogen, phosphorus and potassium on growth and yield of wheat. Pak. J. Agric. Res., 14:126-130.

[22] Khursheed, M. Q., and Mahammad M. Q. (2015). Effect of Different Nitrogen Fertilizers on Growth and Yield of Wheat. Zanco J. Pure of Applied Sci., 27: $19-28$

[23] Kindred, D. R., Tamara M. V., Richard W. M., Stuart S. J., Reginald C. A., James M. Brosnan, SylvesterBradleya R. (2008). Effects of variety and fertilizer nitrogen on alcohol yield, grain yield, starch and protein content, and protein composition of winter wheat. J. Cereal Sci., 48: 46-57.

[24] Laghari, G. M., F. C. Oad, S. D Tunio, A. W. Gandahi, M. H. Siddiqui, A. W. Jagirani, Oad S. M. (2010). Growth yield and nutrient uptake of various wheat cultivars under different fertilizer regimes. Sarhad J. Agric. 26: 489-497.

[25] Lopez, H. W., Leenhardt F., Coudray C., Remesy C. (2002). Minerals and phytic acid interactions: is it a real problem for human nutrition? Int J Food Sci Technol 37: 727-739.

[26] MacLeod, L. B. (1969). Effects of N, P, and K and Their Interactions on the Yield and Kernel Weight of Barley in Hydroponic Culture1. Agron. J., 61:2629.

[27] Malghani, A. L., Asmat Ullah Malik, A. Sattarb, Fiaz Hussaina, G. Abbasc and J. Hussain, (2010). Response of growth and yield of wheat to NPK fertilizer. Sci. Int. (Lahore), 24:185-189 
[28] Maqsood, M., Abid A. M., Iqbal A., Hussain M. I. (2001). Effect of variable rate of nitrogen and phosphorus on growth and yield of maize (golden). Online J. Biol. Sci. 1:19-20.

[29] Marschner, H. (1995). Mineral nutrition of higher plants, PP: 148-73. Academic press inc., San Diego. USA.

[30] Menger, A., (1976). Effect of raw materials and processing conditions on pasta quality. English Abs. From Getreide, -Mehl-und-Brot, 30: 149-155.

[31] Nag, A. (2016) Techniques in agricultural, Environmental and Food Engineering, $3^{\text {rd }}$ ed. PHI learning private limited, Delhi- 110092, pp 39-41.

[32] Niamatullah, M., M. Khan, M. Q. Khan, M. Sadiq, K. U. Zaman, C.S. Hayat and S. Rehman, (2011). Impact of NPK application on the number of productive tillers and cost benefit analysis of wheat in Hill-Torrent irrigated area of D. I. Khan division, Khyber Pakhtoon Khwa. J. Anim. Plant Sci., 21: 211-214

[33] Nogueira, S. S. S., V. Nagai; N.R. Braga; M. Do C.S.S. Novo, Camargo M. B. P. (1994). Growth analysis of chickpea (Cicer arietinum L.). Sci. agric., Piracicaba, 51:430-435,

[34] Raboy, V. and D. B. Dickinson (1984). Effect of phosphorus and zinc nutrition on soybean seed phytic acid and zinc. Plant Physiol., 75: 1094-1098.

[35] Raboy, V., (2001). Seeds for a better future: 'Low phytate' grains help to overcome malnutrition and reduce pollution. Trends in Plant Science 6: 458462.

[36] Rosa M., G. Estepa, E. G. Hernandez and B. G. Villanova, 1999. Phytic acid content in milled cereal products and breads. Food Res. Int., 32, 217-221.

[37] Saha, S., Bholanath Saha, Sidhu Murmu, Sajal Pati, Partha Deb R. (2014). Grain yield and phosphorus uptake by wheat as influenced by long-term phosphorus fertilization. Afr. J. Agric. Res., 9: 607612.

[38] Sameen, A., Abid Niaz, Anjum, F. M. (2002). Chemical Composition of Three Wheat (Triticum aestivum L.) Varieties as Affected by NPK Doses. Int. J. Agri. Biol., 4: 537-539.

[39] Sheoran, H. S., B. S. Duhan, K. S. Grewal, Sheoran S. (2015). Grain yield and NPK uptake of wheat (Triticum aestivum L.) as influenced by nitrogen, vermicompost and herbicide (Clodinafop propargyl). Afr. J. Agric. Res., 10: 3952-3961.

[40] Shiferaw, B., M. Smale H. J. Braun, E. Duveiller, M. Reynolds, Muricho G. (2013). Crops that feed the world 10. Past successes and future challenges to the role played by wheat in global food security. Food Sec., 5:291-317.
[41] Wilhelm, W.W. (1998). Dry matter partitioning and leaf area of winter wheat grown in a long term fallow tillage comparison in U.S. Central Great Plans. Soil and Tillage Res., 49: 49-56.

[42] Wuest, S. B., Cassman K. G. (1992) Fertilizernitrogen use efficiency of irrigated wheat: II. Portioning efficiency of preplant versus late-season application. Agron. J., 84: 689-694.

[43] Ziadi, N., G. Belanger, A.N. Cambouris, N. Tremblay, M.C. Nolin and Claessens A. (2008). Relationship between phosphorus and nitrogen contents in spring wheat. Agron. J. 100: 80-86. 